\title{
Social Competences of Employees. Feeling of Injustice of Professional Competence Assessment in Opinions of Company Workers
}

\author{
Beata Mazurek-Kucharska \\ SWSPiZ Academy of Management
}

\begin{abstract}
The article presents the results of the author's own empirical studies, conducted within her scientific paradigm, allowing for comparing real results of the social competences (SC) level of Polish workers from enterprises $(n=208)$ with the subjective assessment of their competences level estimated by their superiors. The psychological SC Questionnaire was used to measure the SC. The satisfaction of a worker from the already received assessment of their potential made by the direct superior was measured by means of Questionnaire - QFOI and the quality method - IDIs. The analyses show that there are differences between a profile of employees' SC and a prolife evaluated by their superiors. In most cases superiors estimated the level of employees' SC significantly lower. The subjects claim that they experience the feeling of injustice while assessing their professional competence in their workplace.
\end{abstract}

Key words: social competences, employability, attribution theory, feeling of injustice, assessment of competences, psychological methods.

\section{Introduction}

In the times of continuous economic and social changes, constantly changing economic, cultural and social conditions, social competences seem to be one of the most important dimensions of functioning. They play a significant role in private, social and professional life. According to many researchers and practitioners of labour market, it is individualistic competences and predispositions that are responsible, to a great extent, for successes and failures in the process of planning one's own professional career, making decisions 
connected with it, estimating the risk and the adaptation in the new and, not so rarely, multicultural work environment ${ }^{1}$.

The problem of social competences has a special place both in the modern psychology and in the management sciences. The development of the concept, approaches and methods of studying competence is both the reflection of changes in perceiving the very term 'competence' and the reflection of the development of the interdisciplinary approach towards the understanding of complicated aspects of human functioning during various social changes and the strive for one's individuality and independence.

The development of multi-directional studies and discussions over the essence of social competences, their structure and possibilities of their scientific measurement took place in the late eighties and the beginning of nineties of the twentieth century.

There are many approaches towards understanding the term 'social competences'2.

As Dodge writes ${ }^{3}:$ „... the number of definitions of social competence (...) today approaches the number of investigators in the field" (p. 3).

According to Cavell ${ }^{4}$ all attempts trying to define the term 'social competences' come down to formulating their range either as: a) a product of social functioning, or as b) the requisite skills of social functioning, or c) social functioning per se.

Among the concepts dealing with social competences as the product of social functioning, according to Cavell ${ }^{5}$, we can take into account those concepts

${ }^{1}$ Cf. eg. the discussion presented in: Global Social Change: Historical and Comparative Perspectives, Eds. Ch. Chase-Dunn, S. Babones, The Johns Hopkins University Press, Baltimore, Maryland, 2006; Handbook of multicultural competencies in counseling and psychology, Eds. D.B. Poppe-Davies, H. L. K. Coleman, W. Ming Liu, R. L. Toporek, SAGE Publications, Thousand Oaks, 2003. However in Poland the discussion to be found e.g. in publications: Standardy europejskie $w$ zarzqdzaniu zasobami ludzkimi, ed. M. Juchnowicz, Poltext Warszawa 2004 and in the thesis: M. Sidor-Rządkowska, Kompetencyjne systemy ocen pracowników, Wolters Kluwer, Kraków 2006.

2 The review of these ideas was presened in detail in the thesis: B. Mazurek-Kucharska, Kompetencje społeczne we wspótczesnej psychologii i teorii zarzqdzania. Przegląd wybranych podejść i problemów (Social competence in modern psychology and management theory. A review of selected approaches and problems), in: Kompetencje społeczno - psychologiczne ekonomistów i menedżerów. Teoria, badania, edukacja, Ed. S. Konarski, Warszawa, Oficyna Wydawnicza SGH, pp. 55-94, 2006 (edition I), 2008 (edition II).

${ }^{3} \mathrm{~K}$. A. Dodge, Facets of social interpretation and the assessment of social competence in children, in: Children's peer relation. Issues in assessment and intervention, Eds. B. H. Schneider, K. H. Rubin and J. E. Ledingham, Springer-Verlag, New York 1985, pp. 3-22.

${ }^{4}$ T. Cavell, Social adjustment, social performance, and social skills: A Tri-Component model of Social Competence, „Journal of Clinical Child Psychology” 1990, Vol. 19, No 2.

${ }^{5}$ Ibidem. 
and studies where the emphasis is put on the analysis and measurement of social attainment and global judgement of social competences and studies and measurement of peer acceptance (e.g.: Coie $^{6}$; Dodge i Murphy ${ }^{7}$; Mc Fall ${ }^{8}$ ). Competences treated as a product of social functioning (e.g. social attainment, indicators of social adaptation, capacities for leadership, acceptance in a peer group, social popularity, playing social roles, social solving problems etc.) are understood by the cited researchers as supposed and accumulated consequences of effective social functioning of a human entity in society.

In the classical longitudinal studies of Rowley and Feather from 1987 it is stated that psychological features are important predictors of the achieved professional status. Those who lost their job in the past (or who did not take it up at all) were more prone to stronger depression and stress symptoms, lower life satisfaction, lower assessment of their own competences and more external locus of control. My own studies also confirm this direction of influence ${ }^{9}$. They allow formulating a thesis on the influence of subjective perception context and the assessment of professional competence on making decisions connected with the management of this potential ${ }^{10}$. Therefore it can be assumed that the

${ }^{6}$ D. Coie, Fitting social skills intervention to the target group, in: Children's peer relation. Issues in assessment and intervention, Eds. B. H. Schneider, K. H. Rubin and j. E. Ledingham, SpringerVerlag, New York 1985, pp. 141-156.

${ }^{7}$ K. A. Dodge, R. R. Murphy, The assessment of social competence..., op. cit.

${ }^{8}$ R. M. McFall, A review and reformulation of the concept of social skills, "Behavioural Assessment" 1982, No. 4, pp. 1-33.

${ }^{9}$ The review of these studies was presented in detail in the theses: B. Mazurek-Kucharska, Oczekiwania pracodawców oraz czynniki sprzyjajace odnoszeniu przez młodzież sukcesów na rynku pracy, in: Nowoczesne poradnictwo zawodowe i pośrednictwo pracy dla młodzieży, Ed. E. Giermanowska, J. Kotzian, HRK S.A., HRM Partners, Warszawa 2011, pp. 59-67; B. Mazurek-Kucharska, Uwarunkowania atrakcyjności zatrudnieniowej i sukcesu w opinii rodziców powracajacych do aktywności zawodowej (Conditions for success and employability of the employment in the opinion of parents returning to professional activity), „Edukacja Dorosłych”, No. 1 (64), Wydział Pedagogiczny Uniwersytetu Warszawskiego, Akademickie Towarzystwo Andragogiczne, 2011, pp. 77-100.

10 B. Mazurek-Kucharska, Kompetencje społeczne młodzieży, in: Młodzież na rynku pracy - od badań do praktyki, część II - Badania mtodzieży jako podstawa diagnozowania i prognozowania jej sytuacji zawodowej, Eds. S. M. Kwiatkowski, Z. Sirojč, Oficyna Wydawnicza ASPRA - JR, Warszawa 2006, pp. 93-121; B. Mazurek-Kucharska, Kompetencje menedżera - stereotyp polski i australijski. Badania międzykulturowe, „Edukacja Ekonomistów i Menedżerów”, April 2006, Oficyna Wydawnicza Szkoły Głównej Handlowej, pp. 161-183; B. Mazurek-Kucharska, Diagnoza psychologiczna w programach wspierajacych aktywizację zawodowa, pp. 9-44, in: Praca, ksztatcenie, partnerstwo. Zbiór opracowań powstatych $w$ ramach programu Phare 2000 „Rozwój Zasobów Ludzkich”; Ed. M. Kubisz, Polska Agencja Rozwoju Przedsiębiorczości, Warszawa 2004; B. Mazurek-Kucharska, Raport końcowy Projektu: Perspektywy i oczekiwania: Mazowiecki Rynek Pracy dla Młodzieży, MWK OHP, Warszawa 2007. 
professional situation of a person and the attractiveness of his/her employability are conditioned not only by the objective (measureable, possible to examine thoroughly by means of psychometrical tools) level of professional competence, but also by the subjective assessment of their possibilities (in the assessment of a given unit and in the assessment of potential employers, business and social partners, as well as representatives of institution of the labour market).

Therefore, it can be assumed that there are probably simplified patterns of perception and professional potential competence such as: scripts, stereotypes, cultural models or attitudes or expectations, which may influence professional competence assessment and even estimation of human capital worth. They can also influence making decisions connected with the management of professional competence and the valuation of its worth.

The above formulated thesis was verified in the already mentioned, previously conducted interdisciplinary studies of my own in this matter, engaging the knowledge of management as well as psychology.

In this article I will present the results of a chosen part of my own empirical studies, conducted within the author's scientific paradigm, allowing for comparing real results of the social competences level of a studied person with the subjective assessment of their competences level estimated by their superiors. The presented analysis deals with professional competences of Polish workers from enterprises - people from different social environments and of different social status - how the workers assess themselves and how their employers assess them ${ }^{11}$. The analysis will be supplemented with the results of a questionnaire filled in by these workers about their satisfaction assessment based on the already received information about their social competence potential.

\section{Professional potential assessment and attribution theory in psychology}

The assessment of individual and other people's features and their comparison with each other is the subject of debates of social psychologists including followers of numerous theoretical concepts describing the phenomena of social attribution.

${ }^{11}$ The presented study was partially financed from the Fund for Own Research of Collage of Collegium Administration at Warsaw School of Economics in 2008, continued from own funds of the author's. 
The attribution theory is connected with seeking the reasons for events, phenomena, experiences and assessment underlying the world we learn and relations ruling it. Attribution studies deal with the way human beings choose, process, preserve, remember and assess their own information (important for inferring) and how this information is used to draw conclusions and settle the reasons for hidden bases of phenomena ${ }^{12}$. It is assumed that in the situation when there is no important information humans will look for it because the motive of cognition and understanding themselves and the world are important motives of humans' functioning.

Attribution involved in assessing others is understood as a process of attributing specific features (personality, competence, behaviour), or the system of values, needs, motives based on the process of inference to other people or to oneself What is involved in it is the process of analysis and assessment of outer (observable) behaviour e.g. utterances, mimes, gestures, and the style of communicating with the surroundings. What can also influence the process of inferring are personal approaches, thinking patterns, stereotypes, attitudes and expectations of a human carrying out such an analysis.

Perceiving people is called social perception, interpersonal perception or social perceiving. It is a complex process on a higher level of analysis, the so-called semantic and operational level. It differs from simple perception called figure perception which is on the lower level, so called sense and motor level of an object's feature analysis (e.g. colour, shapes and figures perception). Social perception deals in not only the reflection of features, the observation of other people's behaviour, but also on interpreting, selecting, processing or integrating individual (in that sense subjective) information about the object of the perception ${ }^{13}$.

In the process of interpretation of individual features there is the activation of so called cognitive patterns of processing complex meaningful information (for example individual features, relational features, valuation and categorization) of separate dimensions. Cognitive patterns are complex, multidimensional mental objects (also called scripts, scenarios, judgements), which, because of the fact that they engage enormous mental operations, aim at the simplification of complicated procedures. The system of processing complicated and multimodal information aims at effective management of attention, perception, memory and formal thinking, in other words at saving the means of cognitive system,

12 See e.g. F. Försterling, Attributions. An introduction to theories, research and applications, Psychology Press Ltd., Philadelphia 2001.

13 See: e.g. T. Mądrzycki, Deformacje w spostrzeganiu ludzi, PWN, Warszawa 1986. 
creating necessary energetic and mental reserves which can be needed to solve another informational problem at any moment. Therefore, in the attribution process simplified procedures take place to infer about others' (but also own) features, competences, motives of actions and hidden needs.

Similar patterns of simplified inference about immanent (hidden) dimensions (e.g. social competences, intelligence, talents) can function during our perceiving other people we communicate directly or indirectly with, during employing, recruitment, selection or professional assessment. It takes place especially when we need to rely on our own intuition and knowledge, which is when standardized, reliable and precise methods of competence, intelligence and personality measurement are not used. It is natural that every day we assess, compare and valuate other people and ourselves in different social contexts using the mechanisms described by the attribution theories.

Therefore, the process may influence the attractiveness assessment (e.g. employment attractiveness) of the person being assessed. What seems to be very interesting is the cognition of possible occurrence of mechanisms of simplified attribution in assessing our own and others' professional competence (chosen features, behaviour, attitudes and motives).

\section{Professional potential of assessed people and attribution theory. Author's own study}

Empirical study has been made to conduct the analysis of possible occurrence of simplified patterns of perception and assessment of professional potential.

\section{Questions and research hypothesis}

The following research questions were posed:

According to respondents, in the process of professional potential assessment are simplified patterns of concluding about chosen dimensions of a particular person's social competences used?

And further questions:

In the process of inferring about hidden dimensions of professional potential of a person being studied, do the people from the direct working surroundings (employer, co-workers) tend to subjectively assess professional potential of the person being studied, or is the assessment reliable and just?

It was expected that it would be possible to verify the following research 
thesis statement: According to respondents, in the process of professional potential assessment simplified patterns of inferring about chosen dimensions of a given person's social competences are used.

Thus: people from the direct surrounding of a person being studied (their superior, co-workers) tend to subjectively assess professional potential of the person being studied.

The examined were asked to refer to the assessment made so far by their direct superiors and co-workers as they are the people who most often assess our professional potential (using concrete methods of measurement of these competences or by voicing their opinion within the system procedures of working period assessment), give us feedback about it and make decisions connected with it that directly refer to us (educational or professional decisions etc.).

The posed questions seem to be of great social importance. We ask if, according to workers, while assessing their professional and employment attractiveness (measured with, for example, the level of chosen social competences), important people use a simplified (which is false and stereotypical) assessment of the level of respondents' competences, or if the assessment is thorough, reliable and just (close to the assessment resulting from the conducted measurement by means of reliable methods assessing the level of these competences - for example using psychometrical methods).

It is worth remembering that both extortionate and lowered assessment of others' potential may become a source of wrong decisions (recruitment and selection) or even refusal to make any decisions (e.g. through resenting from employing or promoting a person who seems to present inappropriate level of professional competences required in a particular situation).

\section{Stages of study}

A four-levelled study was planned:

1. measurement of professional potential of a proper person being studied (respondent) (the study with the use of the Social Competences Questionnaire - SCQ)

2. giving the studied respondents the feedback about the achieved results of the measurement of their competences (giving the individual competence profile together with the comments about it)

3. estimation of the level of professional potential of a person by his or her direct superior (filling the SCQ by the superior in such a way that, in his/ 
her opinion, their worker-respondent would fill in the form); the results of this study were not available for the studied respondents-workers

4. measurement of the respondent's satisfaction from the assessment received so far about his/her potential, made by the direct superior and co-workers (e.g. within the period working assessment, during discussions connected with work effects assessment, during considering requests for promotions or raising salary etc.); the satisfaction of the workers was examined by means of the author's Questionnaire Survey QFOI; the results of this study were not available to the studied respondents-superiors ${ }^{14}$.

The plan of the research is schematically shown in Figure 1.

Figure 1. Stages of empirical study

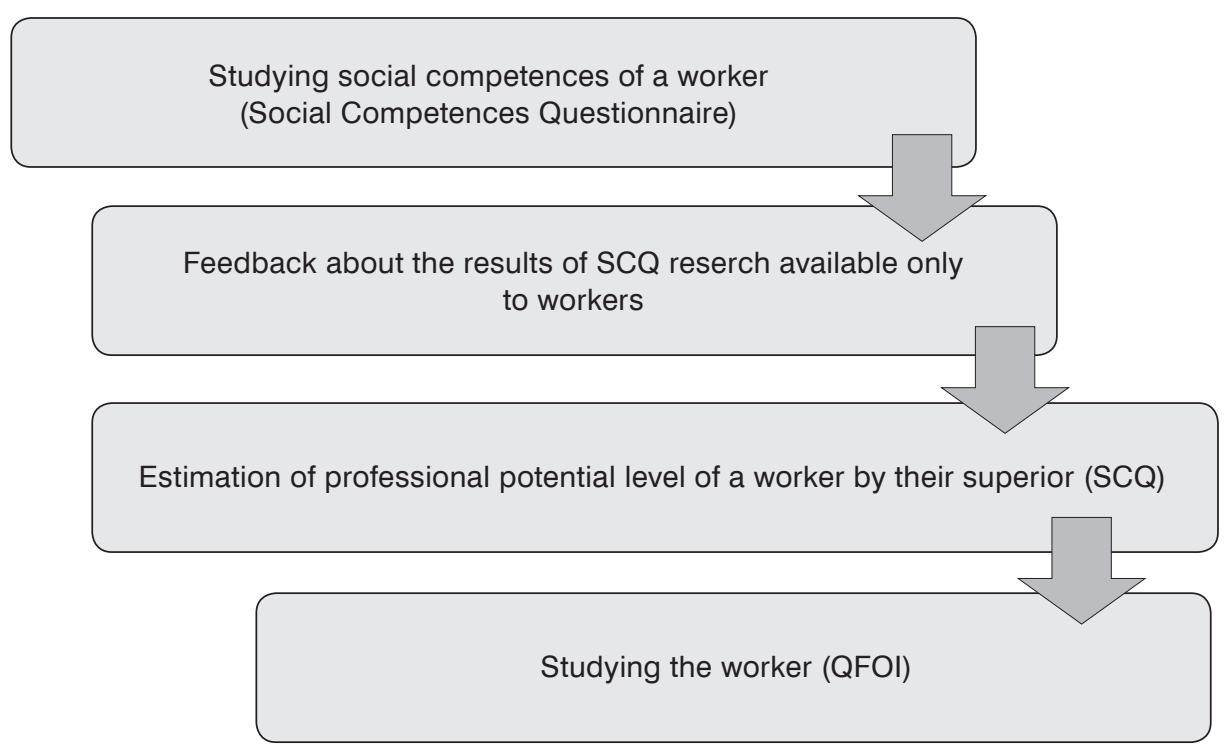

Source: own study

${ }^{14}$ The detailed discussion of the results of the study at the stages 1,2 and 3 exceeds the present paper; the results will be only mentioned during the analysis. Their discussion in detail is presented in the reviewed final report of the study: B. Mazurek-Kucharska, Percepcja i subiektywna ocena wtasnego i cudzego potencjatu kompetencyjnego w kontekście atrakcyjności zatrudnieniowej i sukcesu na wspótczesnym rynku pracy (Reviewed the final report of perception and subjective evaluation of their own and others' competence in the context of the potential attractiveness of the employment and success on the contemporary labor market), Report, Szkoła Główna Handlowa, Warszawa 2009. 


\section{Research methods}

The Social Competences Questionnaire (SCQ) was used to measure professional potential. The satisfaction of a worker from the already received assessment of their potential made by the direct superior and co-workers was measured by means of Survey Questionnaire - QFOI and the quality method (individual depth interview $-I D I)^{15}$.

At the first stage the Social Competences Questionnaire (SCQ) was used. The author of this psychometrical method is A. Matczak ${ }^{16}$. It is a standardized method of the diagnose of chosen social competences. The questionnaire is constructed in such a way that it is possible to measure correctly social competences understood as complex abilities that condition the effectiveness of managing in specific social situations. The SCQ is a self-descriptive questionnaire whose positions are descriptions of different activities and tasks written in an infinitive form. Some of them deal with different social activities (60 positions); the remaining positions (non-diagnostic) deal with activities which are of nonsocial character (30 positions). The categories of the diagnostic positions, namely those examining social competences, include four types of situations:

a. intimate situations - meaning very close interpersonal contacts and connected with far reaching revealing oneself to a partner (e.g. telling about personal problems, or the situation of listening to such a confession);

b. situations of social exposition - i.e. being in the centre of attention and an object of a potential assessment made by many people;

c. formal situations - requiring the adaptation to strictly described rules and regulations;

d. situations demanding the assertiveness (fulfilling one's own aims or needs by making a pressure on others or by resisting such a pressure).

The results are grouped according to three diagnostic scales: scale I competences conditioning the effectiveness of behaviour in intimate situations, scale ES - competences necessary in the situations of social exposition, and scale A - competences used in situations requiring assertiveness.

The answers to particular diagnostic positions are pointed in the scale from 1 (the answer: 'definitely wrong') up to 4 (the answer: 'definitely good').

${ }^{15}$ In the present paper only parts of the study will be presented, with the use of the SCQ Questionnaire and QFOI. The detailed analysis with the use of all psychometrical methods and deepen individual interview exceeds the present paper.

16 A. Matczak, Kwestionariusz Kompetencji Społecznych, Pracownia Testów Psychologicznych Polskiego Towarzystwa Psychologicznego, Warszawa 2001. 
The studied person's received total result is the sum of all points received through answering all diagnostic questions (minimal raw sum is 60 points, and maximal is 240). Raw results (RR) relate to their standard ten. The test standards are Polish and they come from the nineties of the twentieth century. The results can be interpreted as: low (1-3 standards), average (4-7 standards) or high (8, 9 and 10 standards).

\section{Characteristics of examined subjects}

The people studied at the first stage were women $(n=126)$ and men $(n=82)$, working in micro, small and average enterprises in the areas of Lublin, Masovia and Silesia. The detailed structure of the test with regard to the studied person's sex is shown in Table 1.

Table 1. The structure of the test with regard to the studied people's sex

\begin{tabular}{|c|c|c|c|}
\hline Sex & Frequency & Per cent & Accumulated per cent \\
\hline Men & 82 & 39.4 & 39.4 \\
\hline Women & 126 & 60.6 & 100.0 \\
\hline Total & 208 & 100.0 & \\
\hline
\end{tabular}

Source: own study based on empirical data

The studied were workers of three different types of enterprises: micro, small and average. Almost $78 \%$ were workers of small and average enterprises, and only a little over $22 \%$ - of micro companies.

Table 2. The structure of the test with regard to the type of an enterprise where the studied person works

\begin{tabular}{|l|c|c|c|}
\hline $\begin{array}{c}\text { Type of an } \\
\text { enterprises }\end{array}$ & Frequency & Per cent & $\begin{array}{c}\text { Accumulated per } \\
\text { cent }\end{array}$ \\
\hline micro & 46 & 22.1 & 22.1 \\
\hline small & 87 & 41.8 & 63.9 \\
\hline average & 75 & 36.1 & 100.0 \\
\hline Total & 208 & 100.0 & \\
\hline
\end{tabular}

Source: own study based on empirical data

The arrangement of women and men in the study with regard to the type of an enterprise where the studied person works is shown in Table 3. 
Table 3. Structure of the test with regard to the type of an enterprise where a studied person works - including the structure of the studied people's sex

\begin{tabular}{|l|c|c|}
\hline \multirow{2}{*}{ Type of enterprise } & \multicolumn{2}{|c|}{ Sex } \\
\cline { 2 - 3 } & Men & Women \\
\hline micro & 18 & 28 \\
\hline $\begin{array}{l}\text { small } \\
\text { average }\end{array}$ & 37 & 50 \\
\cline { 2 - 3 } & 27 & 48 \\
\hline
\end{tabular}

Source: own study based on empirical data

Therefore the most numerous group of the studied were women and men from small enterprises $(n=87)$, the least frequent group were men from micro companies.

Every studied person attended three meetings (stages 1, 2 and 4).

\section{Analysis of the results of empirical study}

At the first stage of the study professional potential of the studied was measured by means of the Social Competences Questionnaire ${ }^{17}$.

The average raw results of this measurement received by the studied are shown in Table 4.

Table 4. Structure of average raw results according to particular scales of Social Competences Questionnaire of the studied people

\begin{tabular}{|l|c|c|c|c|}
\hline \multicolumn{1}{|c|}{ Scale of SCQ } & $\begin{array}{c}\text { Average } \\
\text { lowest } \\
\text { result }\end{array}$ & $\begin{array}{c}\text { Average } \\
\text { highest } \\
\text { result }\end{array}$ & Average & $\begin{array}{c}\text { Standard } \\
\text { deviation }\end{array}$ \\
\hline Intimate Contacts Scale & 34.00 & 54,00 & 44.08 & 5.35 \\
\hline Assertiveness Scale & 34.00 & 63,00 & 47.30 & 6.59 \\
\hline Social Exposition Scale & 34.00 & 70.00 & 52.48 & 7.07 \\
\hline TOTAL RAW RESULT (Total) & 127.00 & 222.00 & 175.86 & 19.59 \\
\hline
\end{tabular}

Source: own study based on empirical data

${ }^{17}$ The detailed discussion of the results at the first stage is presented in the reviewed report: B. Mazurek-Kucharska, Percepcja i subiektywna ocena wtasnego i cudzego potencjatu kompetencyjnego..., op. cit. 
The detailed analysis of individual and professional profiles is not the most important at this point. What is more important is signalling the characteristic phenomenon revealed in the process of the study at the stage 3 (superiors' research). As a result of the conducted analyses it was revealed that employers filling in the SCQ just as if, in their opinions, their workers filled it in, estimated the level of social competences on the lower level than the real one. It is shown in Figure 2.

Figure 2. Profile of a worker's competences and a profile indicated by their superior (raw results $-\mathrm{RR}$ )

Comparison of profiles of SCQ: profile of the examined person and profile indicated by their supervisor

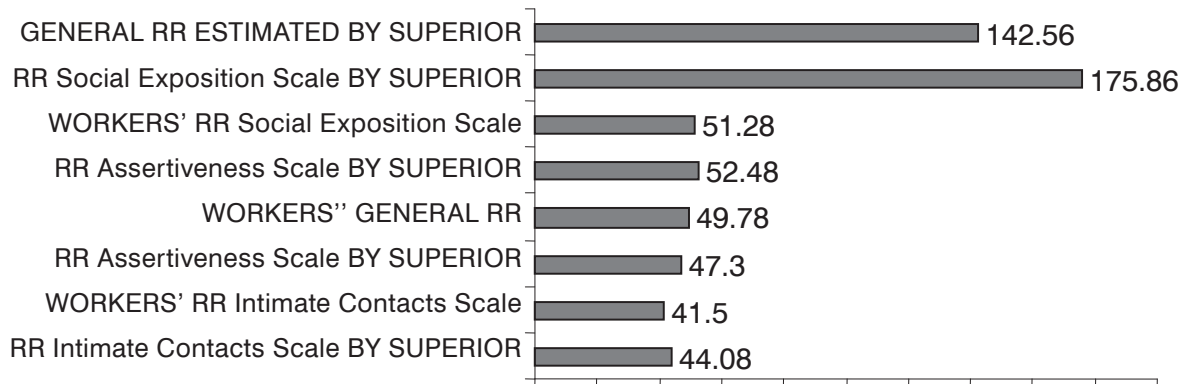

$\begin{array}{llllllllll}0 & 20 & 40 & 60 & 80 & 100120 & 140 & 160 & 180 & 200\end{array}$

Source: own study based on empirical data

As the conducted analyses show there are differences between different scales of social competences which particular studied people receive and which are evaluated by their superiors.

In most cases superiors estimate the significantly lower level of social competences of a studied worker.

It is shown especially during the estimation of competences according to the Intimate Contacts Scale. This scale measures the general emotional intelligence which is revealed in the quality of direct contacts with the other person, especially when these people are emotionally involved and expect emotional behaviour showing the emotional maturity and sensitivity (empathy).

The fact that superiors lower the result of their employees according to this scale may be conditioned at least by two different factors.

Firstly, employees may really cause problems connected with emotional immaturity or the lack of accord with their superiors (at least the supervisor perceives it in such a way). 
Secondly, however, the lack of accord and emotional problems between people may result also from the reasons attributable to the superior: generally quite a high level of emotional sensitivity of a studied person (which was received in a reliable measurement of a worker by the SCQ Questionnaire) may encounter communication and psychological barriers made by the superior. It is a possible explanation since the studied workers' objective results of the test do not tell about serious psychological problems, which could be attributable to a worker.

These facts may also be interpreted more broadly - within the attribution theory which underlines the meaning of approaches, cognitive patterns, roles, attitudes and other social factors in the analysis of other people's features perceived by us.

At the final stage of analyses the results of the research were summarized with the use of QFOI Questionnaire (the fourth stage). The aim of this study was to determine the satisfaction of workers from the already gathered information about their professional potential dealing, to a great extent, with social competences.

Disturbing facts were revealed.

Firstly, only two people (out of 208 studied) have ever had a professional test of competence with the use of objective methods of measurement using psychometrical tests. None of the studied has ever undergone a psychological test aiming at the evaluation of their professional potential and professional preorientation. None of them knows their result of general intelligence or emotional intelligence as they have never taken part in such a study. Over $85 \%$ of the studied have not undergone any professional test while being recruited or while working. Only seven people have had a direct talk with their superior during the recruitment (these were workers of micro and small enterprises), and 24 people have had such a talk with some other worker (a part of the respondents did not know what post the speaker was employed in). Over half of the studied $(67 \%)$ claim that the assessment of their competences by their direct superior is unreliable, not objective and is not conducted on purpose.

What is the most dramatic of all in the analyses: 187 of the studied people claim that they experience the feeling of injustice while assessing their professional competence in their workplace. The feeling of injustice refers both to the lack of objective, reliable and accurate methods of studying these competences, as well as the feeling of injustice in the process of planning their careers in enterprises, influencing their further professional development and allowing workers to participate. The workers claim that it refers not only to themselves but to their co-workers as well. 
It is worth pointing out that the feeling of injustice as such has become the matter of scientific research ${ }^{18}$. The researchers are aware of the consequence of negative attitudes which may influence both the quality of interpersonal relations and the quality of management.

The feeling of injustice is not an objective factor. It does not undergo an objective measurement and does not allow for comparing its intensity in a person with its intensity in other people. It is a totally subjective and intrapersonal factor. It is subjective in such a way that each and every one of us perceives and feels the surrounding world, phenomena occurring in it and our relations with other people. It is subjective in such a way as the attribution theory assumes. It does not mean, however, that subjective perception of phenomena, facts and relations should not be the subject for social studies. The results of such studies should be an inspiration for further analyses, and revealed negative attributions should encourage changing and building relations based on transparent rules of mutual responsibility and sensitivity.

\section{Conclusions}

The conclusions drawn from the analyses may serve to plan further studies over the usage of the attribution theory in the analysis of facts connected with management, especially the management of relations and human capital in enterprise. Therefore, they may be, to some extent, helpful in understanding the complexity of the process of social perception and mutual assessment of participants in business and social relations.

They may be helpful in understanding multidimensional phenomena connected with the attribution: our perceiving features and behaviour of other people including our employees, superiors and co-workers.

${ }^{18}$ See e.g.: D. M. Kappen, N. R. Branscombe, The effects of reasons given for ineligibility on perceived gender discrimination and feelings of injustice, "British Journal of Social Psychology”, 2001, 40, pp. 295-313; M. Miceli, C. Castelfranchi, The envious mind, „Cognition and Emotion” 2007, 21 (3), pp. 449-479. 


\section{Bibliography}

Cavell T., Social adjustment, social performance, and social skills: A Tri-Component model of Social Competence, „Journal of Clinical Child Psychology” 1990, Volume 19, No 2.

Coie D., Fitting social skills intervention to the target group, in: Children's peer relation. Issues in assessment and intervention, Eds. B. H. Schneider, K. H. Rubin, J. E. Ledingham, Springer-Verlag, New York 1985.

Dodge K. A., Facets of social interpretation and the assessment of social competence in children, in: Children's peer relation. Issues in assessment and intervention, Eds. B. H. Schneider, K. H. Rubin, J. E. Ledingham, Springer-Verlag, New York 1985.

Försterling F., Attributions. An introduction to theories, research and applications, Psychology Press Ltd., Philadelphia 2001.

Global Social Change: Historical and Comparative Perspectives, Ed. Ch. Chase-Dunn, S. Babones, Baltimore, Maryland: The Johns Hopkins University Press 2006.

Handbook of multicultural competencies in counseling and psychology, Eds. D. B. Poppe-Davies, H. L. K. Coleman, W. Ming Liu, R. L. Toporek, SAGE Publications, Thousand Oaks 2003.

Kappen D. M., Branscombe N. R., The effects of reasons given for ineligibility on perceived gender discrimination and feelings of injustice, „British Journal of Social Psychology" 2001, 40.

Matczak A., Kwestionariusz Kompetencji Społecznych. Podręcznik, Pracownia Testów Psychologicznych Polskiego Towarzystwa Psychologicznego, Warszawa 2001.

Mazurek-Kucharska B., Diagnoza psychologiczna $w$ programach wspierajacych aktywizację zawodowa, in: Praca, ksztatcenie, partnerstwo. Zbiór opracowań powstatych w ramach programu Phare 2000 „Rozwój Zasobów Ludzkich”; Ed. M. Kubisz, Polska Agencja Rozwoju Przedsiębiorczości, Warszawa 2004.

Mazurek-Kucharska B., Kompetencje menedżera - stereotyp polski i australijski. Badania międzykulturowe (Competence of the manager. The Polish and Australian stereotype. Intercultural research), „Edukacja Ekonomistów i Menedżerów”, April 2006, Oficyna Wydawnicza Szkoły Głównej Handlowej.

Mazurek-Kucharska B., Kompetencje społeczne we wspótczesnej psychologii $i$ teorii zarządzania. Przegląd wybranych podejść i problemów (Social competence in modern psychology and management theory. A review of selected approaches and problem), in: Kompetencje spoteczno - psychologiczne ekonomistów i menedżerów. Teoria, badania, edukacja, Ed. St. Konarski, Warszawa, Oficyna Wydawnicza SGH, 2006 (edition I,), 2008 (edition II).

Mazurek-Kucharska B., Kompetencje społeczne młodzieży, in: Młodzież na rynku pracy - od badań do praktyki, czéść II - Badania mtodzieży jako podstawa diagnozowania i prognozowania jej sytuacji zawodowej, Eds. S. M. Kwiatkowski, Z. Sirojč, Oficyna Wydawnicza ASPRA - JR, Warszawa 2006.

Mazurek-Kucharska B., Oczekiwania pracodawców oraz czynniki sprzyjające odnoszeniu przez młodzież sukcesów na rynku pracy, in: Nowoczesne poradnictwo 
zawodowe i pośrednictwo pracy dla młodzieży, Eds. E. Giermanowska, J. Kotzian, HRK S.A., HRM Partners, Warszawa 2011.

Mazurek-Kucharska B., Perspektywy i oczekiwania: Mazowiecki rynek pracy dla młodzieży, MWK OHP, Warszawa 2007.

Mazurek-Kucharska B., Uwarunkowania atrakcyjności zatrudnieniowej $i$ sukcesu $w$ opinii rodziców powracajacych do aktywności zawodowej (Conditions for success and employability of the employment in the opinion of parents returning to professional activity), „Edukacja Dorosłych”, No 1 (64), Wydział Pedagogiczny Uniwersytetu Warszawskiego, Akademickie Towarzystwo Andragogiczne, 2011. Mądrzycki T., Deformacje w spostrzeganiu ludzi, PWN, Warszawa 1986.

McFall, R. M., A review and reformulation of the concept of social skills, „Behavioural Assessment" 1982, No 4.

Miceli M., Castelfranchi C., The envious mind, „Cognition and Emotion” 2007, 21 (3). Sidor-Rządkowska M., Kompetencyjne systemy ocen pracowników, Wolters Kluwer, Kraków 2006.

Standardy europejskie w zarządzaniu zasobami ludzkimi, Ed. M. Juchnowicz, Poltext, Warszawa 2004.

\section{Резюме}

\section{Общественная компетенция работников. Чувство несправедливости оценки компетенции в мнении работников предприятий}

В статье представлены результаты исследований, проведенных по авторской парадигме, касающейся сравнения реальных профилей общественной компетенции (SC) польских работников предприятий $(\mathrm{n}=208)$ с профилями, какие приписывают им начальники. Для измерения SC использовался психологический Опросник общественной компетенции. Удовлетворение работников, полученное от проведенного до сих пор измерения их компетенции определялось с помощью авторского Опросника QFOI, а также результатов взятых у них индивидуальных углубленных интервью (IDI). Анализы показали, что есть разницы между реальными профилями SC работников и профилями, приписанными им начальниками. В большинстве случаев начальники занижали в оценке уровень SC своих подчиненных. Работники заявляют, что они испытывают чувство несправедливости, когда анализируют полученные до сих пор результаты оценки их SC в рабочей среде.

Ключевые слова: общественная компетенция, привлекательность занятости, теория атрибуции, чувство несправедливости, измерение компетенции, психологические методы. 


\section{Beata Mazurek-Kucharska}

Ph.D. in Psychology, Assistant Professor at SWSPiZ Academy of Management in Warsaw, independent expert in methodology of social research, applying psychology in business; leader, expert and reviewer of Polish and international research projects; expert in projects dealing with the management of competences, management of human resources and applying psychology in business; lecturer and coordinator of the module Managerial Skills at Master of Business Administration studies (University of Central Lancashire, Lublin Business School); lecturer of postgraduate studies at the Faculty of Human Capital Development at the Collegium of Business Administration of the Warsaw School of Economics in Warsaw and other Universities.

Contact: beatakucharska@interia.pl 